\title{
REALIZMUS, MÉRSÉKLET, TRAGÉDIA
}

\author{
Illés Gábor \\ (MTA TK Politikatudományi Intézet, ELTE ÁJK Politikatudományi Intézet)
}

(Szücs Zoltán Gábor: A politika lelke. A politikai realizmus elméleti és eszmetörténeti nézópontból. Budapest, MTA Társadalomtudományi Kutatóközpont, 2018.)

Szücs Zoltán Gábor A politika lelke című könyve a realista politikaelmélet hazai önreflexiójának első monográfiája.* Némileg mesterkélt megfogalmazásom azzal magyarázható, hogy a politikai realizmus mibenlétét, ahogy Szücs is hangsúlyozza könyvében (41-44.), aligha ragadhatjuk meg kielégítően egy definíció segítségével. Sokkal inkább bizonyos toposzok (például: a politika konfliktusos; az univerzális morális normák orientáló ereje korlátozott; az érzelmeknek és a szenvedélyeknek döntő szerepe van a politikában; a rend és a modus vivendi megteremtése nem lebecsülendő politikai teljesítmény; az ítélőképesség kiemelkedően fontos politikusi képesség; az emberek képességeik alapján egyenlőtlenek, stb.) különféle összekapcsolódásai alkotják a különböző realizmusokat. Mondhatnánk akár úgy is, Wittgensteintől kölcsönözve, hogy a realista politikaelméleteket „családi hasonlóságok” kapcsolják össze (Wittgenstein, 1998: 67. §). Sokféle realizmus van tehát, illetve beszélhetünk a realizmus fokozatairól is (minél több realista toposzt integrál magába egy politikaelmélet, annál inkább realista). Ha elfogadjuk ezt a tág realizmusfelfogást, amelyet Szúcs alkalmaz, az 1990 utáni magyarországi politikaelméletnek gazdag realista tradíciója van.

Szücs könyve azzal hoz újdonságot a magyarországi politikaelméletbe, hogy megkísérli az említett előfeltevések egymáshoz való viszonyát szisztematikusan elemezni. Ez azzal a feltételezéssel jár együtt, hogy az egyes toposzok összekapcsolódása nem teljességgel esetleges, legalább bizonyos mértékig - ahogy Szúcs írja - „csomagban fogadjuk vagy utasítjuk el” őket (41.). Ezen törekvésében a kortárs angolszász politikaelmélet egyik aktuális tendenciáját követi, amelyet például William Galston, Andrew Sabl vagy Alison McQueen nevei fémjeleznek (lásd a 42-43. oldal áttekintő táblázatát).

Azok közé tartozom, akik szerint a „,fordítási munka”, azaz a nemzetközi tudományos diskurzust aktuálisan foglalkoztató kérdések hazai politiakelméleti diskurzussal való megismertetése sem lebecsülendő intellektuális tevékenység.

\footnotetext{
* Korábban készült már Szűcs és Gyulai Attila szerkesztésében egy, a realizmus eszmetörténetével foglalkozó tanulmánykötet (Szúcs-Gyulai 2016), illetve megemlítendő a Politikatudományi Szemle 2016/4. számának realizmussal foglalkozó blokkja is.
} 
Mindazonáltal A politika lelke sokkal ambíciózusabb ennél: egyszerre vezet be a kortárs angolszász realista diskurzusba és nyújtja annak átfogó kritikáját. Bár magyar nyelvú munkáról van szó, egyértelmú, hogy Szűcsnek nem csak a magyar közönség számára van sokrétú és érdemi mondanivalója. Az alábbiakban három pontban kísérelem meg illusztrálni, miben is áll ez a mondanivaló, nem törekedve teljességre.

Az elsó sajátosság, hogy A politika lelke stimuláló dialógust folytat több antik szerzővel is: Thuküdidész, Szophoklész, Xenophón és Arisztotelész egyaránt Szücs „,beszélgetőpartnere”. Az antikvitással való foglalkozás azonban nem válik öncélúvá: a könyvnek a kortárs politikai realizmus önvizsgálatára irányuló javaslatai jelentős részben ebből a párbeszédből nőnek ki. Az egyik ilyen „terápiás” javaslat a mai realisták önmeghatározásával kapcsolatos. Szúcs szerint a realista politikaelméletnek nem szabad magát pusztán antimoralizmusként definiálnia. Realistának lenni „kétszer két frontos harcot” (8.) jelent: a realizmus egyszerre antimoralista (a politikai cselekvés nem erkölcsi elméletek gyakorlati alkalmazása) és antiutópista (a politikaelmélet feladata nem elképzelt ideális állapotok leírása). Azonban mindkét fronton óvakodik a másik szélsőségtől is: elutasítja a might is right felfogást (azaz nem gondolja azt, hogy a politikában az erősebbé a jog), illetve az elméletnek valamiféle korlátozott cselekvésorientáló szerepet szán.

Szúcs célja a realizmus kétarcúságának hangsúlyozásával a kortárs realista diskurzus horizontjának tágítása, annak az általa diagnosztizált zsákutcából való kivezetése. Ezt jól szemlélteti, hogy a könyv elválasztja az angolszász politikaelmélet realizmusát a realizmustól mint tágabb intellektuális jelenségtôl, amely megtalálható az antik politikai gondolkodástól a kortárs fikciókig. Ennek a horizont-összeolvadásnak - miként Bernard Williams Shame and Necessityjében - önismereti hozadéka lehet a kortárs realizmus számára. A realizmus kétdimeziósságának például a következő: „Egyrészt, a moralizmuskritika is meglehetősen nagyrészt antiutópikus meggyőződések által van motiválva és nem az erkölcs politikai szerepével kapcsolatos szkepszisből fakad. Az antiutópizmusból adódik számos olyan kérdés, ami a realistákat a politikával kapcsolatban izgatja. És az antiutópizmusból fakad meglehetôsen nagy részt a mainstream politikaelmélettel szembeni realista elégedetlenség is." (233.)

Az antiutópizmus jelentőségét Arisztotelész, Xenophón és Thuküdidész munkásságán keresztül demonstrálja a könyv. Arisztotelész közismerten kritikus Platón tökéletes Államának elméletalkotási stratégiájával szemben, realista rezsimelmélete pedig alkalmas lehet a helyes politikai cselekvés normáinak megalapozására (erről bővebben alább); Thuküdidész méloszi dialógusa azt mutatja be szemléletesen, hogy „az absztrakt érvek érvényessége alá van rendelve a minél pontosabb politikai helyzetértékelésnek" (206.); Xenophón Kürosza és Anabaszisza pedig, szemben Platón Államával és a Törvényekkel, 
valós történeti események közé ágyazva kíséreli meg leírni a megfelelő politikai vezetést (181.).

Szintén az antikvitásból meríti Szúcs javaslatát a realista antimoralizmus által bírált egyik pozícióval, az "erősebbé a jog” (might is right) felfogásával kapcsolatban. Ezzel a pozícióval az a probléma, hogy a gyakorlatban jóformán senki nem vallja, a fogalom "merőben elvont logikai konstrukció" (21.). Míg Thuküdidész athéni követeinek pozíciója (a might is right felfogásának egyik sokat emlegetett esete) a szerző által a végletekig vitt fiktív álláspont, addig Thuküdidésznek a demokrácia zsarnokivá válásától való félelme nagyon is valóságos. De Szúcs szerint ugyanígy a zsarnokság veszélye lebeg a szélsőséges realizmust (Kreón zsarnokságát) moralista pozícióból bíráló Szophoklész szemei előtt, és a realista Xenophón is ennek elkerülésére mutat példát az Anabasziszban. A javaslat tehát: a might is right felfogását helyettesítsük a zsarnokságéval. Utóbbi ugyanis „olyan viszonyítási pont, amely sokkal jobban átélhetôvé és megérthetővé teszi a realizmussal kapcsolatos egyik nagy dilemmát: hogy mi van akkor, ha a politikailag eredményes cselekvés és a morálisan helyes cselekvés között diszkrepancia van" (232.).

A Xenophón által az Anabasziszban festett fejedelem képe azért is fontos Szúcs számára, mert a kortárs realizmusban a legitimitás fogalmára való fókusz miatt a margóra szoruló, Max Webernél és Bernard Williamsnél is megjelenő felelősségetika előképét látja benne. Xenophónnál „a politikai normák nem moralisták, nem a legitimitásban gyökerezőek, ugyanakkor nem is »machiavellisták", viszont nincsenek híján etikai megfontolásoknak" (185.).

Végül, egy további pont, ahol Szúcs az antik szerzőket használja inspirációs forrásként a kortárs realizmus gazdagításához, Arisztotelész már említett rezsimelmélete (208-230.). Az erre való alapozás nem újkeletū, bár inkább marginális a kortárs realizmusban: Andrew Sabl Ruling Passions (2002) címú könyvének koncepcióját kíséreli meg kitágítani. Arisztotelész fő vonzereje a realisták számára az, hogy egyfelől árnyalt, részletgazdag és többszempontú rezsimelméletet ad, amelyben a rezsimtípusok nem élesen, ideáltipikus módon különülnek el egymástól; másfelől azonban nem mond le bizonyos evaluatív szempontok alkalmazásáról. Míg a körülményektől függetlenül legjobb államforma keresését, vagy éppen a „,one size fits all” elképzelést propagáló elméleteket élesen elutasítja, sőt, még az adott körülmények között legjobb államforma keresésével kapcsolatban is óvatos, a politikai rend stabilitása kulcskérdés számára, illetve a zsarnoksággal szembeni ellenszenve is világosan kifejezésre jut. Nem nehéz belátni, hogy egy ilyen rezsimelméleti megközelítésnek lehet mondanivalója olyan jelenségekről, mint a liberális demokratikus rezsimek hibridizációja, vagy - hogy egy ellentétes jelenséget említsek - a liberális demokrácia exportja. Maga Szűcs is utal rá könyvének végén, hogy a rezsimelméleti kérdésfeltevés, illetve Arisztotelész rezsimelmélete nem pusztán az antikvárius érdeklődésû olvasó számára lehet fontos, hanem annak megválaszolásához is, hogy 
„mit is mondhat az ember olyan rezsimekről, amelyeket egyrészt egészükben véve nagyon nehéz nem moralista módon elítélni, másrészt a bennük élést semmivel sem kevésbé csábító opportunista érvekkel igazolni" (234.).

Az antikvitással való termékeny párbeszéd mellett Szúcs könyvének egy második sajátossága, amely alighanem a realizmus belső dilemmáit kevésbé ismerő olvasó számára is szembeötlő, az elméletalkotás általa alkalmazott formája. Ahogy már az előszóban is írja: a realista elméletalkotás tragikus vállalkozás, annak állandó újrafelismerése, hogy a vállalkozás hiábavaló, ám mégis szükség van rá (8.). Ennek oka a kortárs realisták szerint az, hogy „kezdetben volt a tett”: mivel a politikát alapvetően a cselekvők formálják, arról nem érdemes teljességgel koherens és konzisztens, rendszerezett elméletet alkotni. Ahogy Bernard Williams írja: „A kivételes cselekvés [action] az elmélet [theory] előtt jár” (2005, 25.), de ugyanilyen értelemben idézi Raymond Geuss is George W. Bush egy meg nem nevezett tanácsadójának szavait: „,amikor cselekszünk, megalkotjuk a magunk valóságát. És amíg maguk tanulmányozzák azt [...] mi ismét cselekszünk, más valóságokat teremtve, amelyeket majd ismét tanulmányozhatnak. Mi vagyunk a történelem aktorai [...] és maguknak, maguknak mind, csak az marad, hogy tanulmányozzák, amit teszünk." (idézi: Geuss, 2010: viii-ix.). Ha a politikaelmélet elismeri a cselekvés elsődlegességét (még ha nem is gondolja, mint az idézett Bush-tanácsadó, hogy egyes cselekvők szinte bármit megtehetnek), ennek a politikaelmélet formájára mindenképpen kihatással kell lennie. Az elméletnek helyet kell biztosítania a cselekvés elsődlegességének, erre pedig a filozófiai rendszerek aligha alkalmasak. A problémára a realisták egyik kedvelt megoldása a történeteknek biztosított nagyobb súly a politikai elméletalkotásban. A történetek, szemben a rendszeres filozófiával, képesek lehetnek megragadni a cselekvésben rejlő, a formalizálásnak ellenálló kontingenciát. A Williams munkásságát nagyban inspiráló Judith Shklar írja: „[a] történetmesélés nagy intellektuális előnye, hogy nem racionalizálja a valóságos tapasztalat és a történelem irracionalitását. Határozatlanság, zavarosság [incoherence] és következetlenség [inconsistency] nem lesznek elsimítva vagy zárójelbe téve. Konfliktusaink megőrződnek a maguk eldöntetlenségében [inconclusiveness]" (Shklar, 1984: 230. - idézi: Forrester, 2012: 257.). Világos azonban az ilyen stílusú elméletalkotásra leselkedő legfőbb veszély is: a politikaelmélet könnyen átcsúszhat puszta töténetmesélésbe, felszámolva saját elméletstátuszát. Egy realistának tehát óvatosan kell manővereznie, egyszerre kerülve el a cselekvés elsődlegességének tagadását és az elméleti ambíciók túlzott feladását.

Szûcsnek megítélésem szerint sikerül ez a manőverezés. Nem nehéz észrevenni, hogy könyvének legizgalmasabb részei közül számtalan nem formális elméleti érvelés, hanem tág értelemben vett „"analitikus narratíva”, azaz elméleti kérdésfeltevések által „megfegyelmezett” történetmesélés. Elég a Thuküdidészhez és Xenophónhoz (akik formailag történeteket írtak le, de semmiképpen sem tekinthetőek mai értelemben vett történetíróknak) fordulásra, 
vagy éppen a Star Wars-trilógiák elemzésére gondolni. Ami igaz az egyes fejezetekre, az igaz a könyv egészére is: Szúcs képes úgy vegyíteni a történetmesélés és az analitikus fogalmi elemzés múfajait, hogy múve közben megtartja a politikaelméleti munkáktól elvárható koherenciát is: a kétszer két frontos, a „politika lelkéért" folytatott harcként konceptualizált realizmusfogalom összetartja a múvet. Utóbbi, a könyv címét adó metafora pedig beszédes: Szúcs bevallottan az arisztotelészi felfogás („a tragédia lelke a történet”) mintájára konstruálja meg a fogalmat, azt kívánva érzékeltetni, hogy a realizmus kétszer két frontos harca a politika mibenlétéról szól. Azonban az arisztotelészi kapcsolat, ha az elméletalkotás formájára tekintünk, több, mint puszta analógia: hiszen - számomra legalábbis, de aligha ellentétesen a szerző szándékaival Szûcs könyve éppen azt bizonyítja, hogy a cselekvésnek központi szerepet szánó realista elméletalkotásnak is a történetmesélés a lelke. A realista politikaelmélet és az antik tragédia közötti kapcsolat nem is lehetne szorosabb.

A harmadik sajátosság, amelyet érdemes megemlíteni a mú kapcsán, az a fikciós formák felé való tájékozódása. Ez persze önmagában aligha újdonság: mind a morálfilozófiai, mind a politikaelméleti munkák visszatérően fordulnak olyan fiktív történetekhez, amelyek vagy jól illusztrálják elgondolásaikat, vagy alkalmas közeget szolgáltatnak elméleteik kidolgozásához. Azonban alábecsülnénk a fikciós műfajok fontosságát Szücs számára, ha mindössze illusztratív eszközt látnánk bennük, helyzet- és jellemábrázolások gazdag tárházát, amelyek hasznosak lehetnek mondanivalójának gazdagításához. Ugyanígy nem ismernénk fel a fikció tényleges jelentőségét a mú számára, ha - a fentebb leírtak szellemében - pusztán abban látnánk a jelentőségüket, hogy történetek. Miért olyan fontosak tehát? Már érintettem Szúcs azon állítását, amely szerint létezik egy „tágabb értelemben vett politikai realizmus”, amely a politikaelmélet körén jóval túlterjedő intellektuális jelenség, bizonyos problémák és az azokra adott karakterisztikus megoldási javaslatok összessége, és csak korlátozottan önthető elméleti formába. Ez az állítás úgy tehető nagyobb téttel és szélesebb mindennapi relevanciával rendelkezővé, ha megmutatjuk, hogyan is orientálja mindennapi gondolkodásunkat, hogyan is jelenik meg más, szélesebb körben elterjedt múfajokban a realista gondolkodás. Ez a fikció tényleges jelentősége a mú számára, és erre a célra lehet ideális a populáris kultúra Szücs szerint. A Star Wars-elemzésének kiindulópontja, hogy a "sűrü" fikció (amely morális dilemmákat mutat be árnyaltan) és a "kopár" (amely a véletlen és a szükségszerüség erejét ábrázolja plasztikusan) fikció williamsi megkülönböztetéséhez hozzáad egy harmadik típust, az "elhihetö" fikcióét, amely „létrehoz, megteremt egy fiktív világot, amelynek legváratlanabb, legfantasztikusabb elemei sem feledtetik velünk, hogy bizonyos dolgokat elfogadhatónak, hihetőnek érzünk, míg másokról azt gondoljuk, hogy elidegenítenek a fikció világától" (112.). Szúcs szerint az elhihetőség feltétele bizonyos fokú konzisztencia, emiatt lehetséges a Star Wars trilógiáit egységes politikaképpel 
rendelkező alkotásokként olvasni. Így beszélhet ő maga egy moralista politikaképpel dolgozó klasszikus trilógiáról, egy republikánus politikafelfogással operáló előzménytrilógiáról, és egy realista új trilógiáról. Szűcs elemzése utóbbiról bemutatja, hogyan illeszkedik az a rend nélküliség általános realista problematikájába, hogyan jelenik meg a piszkos kezek dilemmája a Rogue One-ban, vagy éppen a weberi felelősségetika elemeinek feszültsége Leia, Holdo és Dameron konfliktusában. Szúcs értelmezései izgalmasak, innovatívak és szemléletesek, még ha helyenként nem is feltétlenül értek velük egyet (Holdo és Dameron konfliktusában én például sokkal inkább láttam a macsóság veszélyeirôl szóló, erősen egyoldalú morális tanmesét, semmint egy vezetési dilemma valóban árnyalt bemutatását).

Ahogy már a szöveg elején is jeleztem, a fentebbi három téma kiemelésekor nem törekedtem teljességre - a könyvnek a realista tradíció modern képviselőivel (Hobbes-szal, Hume-mal, Weberrel) foglalkozó részeit, vagy éppen a legitimitás körül folyó kortárs realista diskurzus kritikáját például nem is érintettem. Ahogy ebből is látható, a Politika lelkének egyik legnagyobb erénye éppen figyelemreméltó intellektuális gazdagsága: az, hogy számtalan forrásból kíséreli meg - szerintem sikerrel - tágítani a kortárs realista gondolkodás horizontját. A másik erény a könyv világos és érthető nyelvezete, illetve jól követhető és letisztult érvei. A politika lelke rendkívül „hálás” olvasmány: a befektetett olvasási energiáért cserébe nagyon sok intellektuális stimulust kap az olvasó. Ezen stílusbeli sajátosságok folytán - szemben sok kortárs realista szöveggel - a munka, vagy legalábbis annak nagyobbik része, nem kizárólag a szúkebb szakmai közönség számára lehet érdekes.

Ha valamivel kapcsolatban hiányérzete lehet a kortárs realista diskurzust figyelemmel követő olvasónak, az a realizmus azon ágának kimaradása a könyvből, amelyet én talán felforgatónak vagy „klausztrofóbiásnak” neveznék. Olyan gondolkodók sorolhatók ide, akiket nem a politikai rend hiánya vagy instabilitása, sokkal inkább a rend túlzott stabilitása, a kreativitást vagy az önálló gondolkodást megbéklyózó hatásai foglalkoztatnak. Én ilyennek tartom a realista klasszikusok közül Max Webert, vagy a kortárs realisták közül Raymond Geuss-t. A kritikai elméletek által inspirált, a politikai képzelőerő szerepét rendszeresen hangsúlyozó Geuss, bár helyenként kap említést, alapvetően marginális szerepet tölt be a múben, Weber pedig csak a felelősségetikával kapcsolatban kerül tárgyalásra - tehát éppen azon momentum kapcsán, amellyel korlátozni akarja az általa egyébként fontosnak tartott felforgató (avagy karizmatikus) cselekvést.

Ezt az észrevehető hiányt azonban két tényező miatt sem gondolom érdemi hiányosságnak. Egyfelől, Szűcs nyílt lapokkal játszik, és már a könyv elején jelzi, hogy „meglehetősen mérsékelt, erősen liberális realistaként” (8.) fog írni, egy ilyenfajta szúkítés pedig a realista tradíció gazdagsága miatt teljességgel indokolható. A realizmus „kétszer két frontos harcként” való konceptualizálása, a might is right helyére egy valóságosabb ellenfél állítása mind az említett mér- 
séklet jegyei a múben. A Politika lelkét teljesen más hangulat lengi be, mint Geuss és Weber "klausztrofóbiás” írásait: bezártság helyett sokkal inkább a nyílt tengeren elszenvedett hajótörés (vö. Blumenberg, 2006) jut az ember eszébe, amikor Szűcs arról ír, hogy „„elkerülhetetlenül szembe kellett néznem számos magától értetődőnek tủnő igazság valódi értékével és a politikai rend törékenységével" (9.). A felforgató realizmus politikaképe olyan, további problémákat vetett volna fel, amelyek alighanem szétfeszítették volna a mú így is sok mindent egyben tartó elméleti keretét. Elég csak arra gondolni, hogy Geuss renegátként elutasítja a Szúcs által a realizmus meghatározó sajátosságának tekintett antiutópizmust, és egy történetiségre érzékeny kontextuális utópia mellett érvel, amelyet alkalmas gondolati eszköznek tart a konformizmus elleni harcban (vö. Geuss, 2016).

Geuss antiliberális kritikai realizmusa és a Bernard Williams-féle liberális realizmus elképzelt összebékítése talán a kontextuális ítélőképesség fogalmával lenne lehetséges: a realista politikaelmélet elsődleges fókuszába tartozó problémák nem időtlenek, hanem nagyban függnek a politikai kontextustól. Az igazi realista érzékeny környezete problémáira, az általa feltett kérdések, az általa alkotott elmélet pedig kora politikai tendenciáira reflektál: stagnálás, ideológiai „megkövülés” idején a képzelőerőt próbálja stimulálni; ha pedig a radikális politikafelfogások kerülnek előtérbe, a politikai mérsékletről ír. A „realista attitưd" ilyen felfogása pesze meglehetősen önkényes konstrukció (talán túlságosan is emlékeztet a trimmer figurájára), és könnyen lehet, hogy ezzel a leírással az itt felsorolt szerzők egyike sem értene egyet. De ha elfogadjuk, az még egy érv amellett, hogy A politika lelke aktuális olvasmány, és nem csak a politikai realizmussal foglalkozóknak érdemes kézbe venniük.

(A könyv letölthető az alábbi linkről: https://politologia.tk.mta.hu/uploads/ files/Politika_lelke_BELIV_korr-02.pdf)

\section{IRODALOM}

Blumenberg, Hans (2006): Hajótörés nézốvel. Metaforológiai tanulmányok. Ford. Király Edit. Budapest, Atlantisz.

Forrester, Katrina (2012): Judith Shklar, Bernard Williams and political realism. European Journal of Political Theory, 11/3. 247-272.

Geuss, Raymond (2016): Reality and its Dreams. Harvard University Press.

Sabl, Andrew (2002): Ruling Passions: Political Offices and Democratic Ethics. Princeton University Press.

Shklar, Judith (1984): Ordinary Vices. Harvard University Press.

Szûcs Zoltán Gábor-Gyulai Attila (szerk.) (2016): A hatalom ködében. Bevezetés a realista politikaelméletbe. Budapest, L'Harmattan.

Williams, Bernard (2005) (szerk: Geoffrey Hawthorn): In the Beginning was the Deed. Realism and Moralism in Political Argument. Princeton University Press.

Wittgenstein, Ludwig (1998): Filozófiai vizsgálódások. Ford. Neumer Katalin. Budapest, Atlantisz. 